\title{
New records and description of the microstructural patterns of guard hair in Conepatus chinga (Molina, 1782) (Carnivora, Skunk) for the states of Paraná and Santa Catarina, southern Brazil
}

\author{
Sérgio Bazilio \\ Elvira de Bastiani * \\ Cláudia Golec \\ Universidade Estadual do Paraná, Campus de União da Vitória, Colegiado de Ciências Biológicas \\ Praça Coronel Amazonas, s/n, CEP 84600-000, União da Vitória - PR Brasil \\ * Autor para correspondência \\ elvirabio@hotmail.com
}

Submetido em 27/04/2014

Aceito para publicação em 29/12/2014

\section{Resumo}

Novos registros e descrição dos padrões microestruturais do pelo-guarda de Conepatus chinga (Molina, 1782) (Carnivora, Mephitidae) para os estados do Paraná e Santa Catarina, Sul do Brasil. Este artigo tem por objetivo apresentar novos registros de Conepatus chinga para os estados do Paraná e Santa Catarina, na região Sul do Brasil, contribuindo para aumentar o conhecimento sobre sua distribuição, além de descrever os padrões microestruturais de seu pelo-guarda. Foram encontrados três espécimes atropelados nas margens da rodovia BR-280, sendo dois no município de Palmas, no Paraná, e um no município de Abelardo Luz, em Santa Catarina. Para a descrição do padrão cuticular e medular dos pelos-guarda, foram confeccionadas 60 lâminas. Conepatus chinga apresenta um padrão cuticular ondeado transversal e um padrão medular anisocélico. A descrição dos padrões microestruturais de $C$. chinga facilita a realização de estudos relacionados à sua ecologia, ampliando as chances de identificação de pelos encontrados em amostras de fezes de carnívoros em estudos mastofaunísticos.

Palavras-chave: Atropelamentos; Mephitidae; Tricologia

\section{Abstract}

This article aims to show new records of Conepatus chinga for the states of Paraná and Santa Catarina, in southern Brazil, contributing to increase knowledge on its distribution, besides describing the microstructural patterns of its guard hair. Three run-over specimens were found in highway BR-280, two of them in the town of Palmas, in Paraná, and one in the town of Abelardo Luz, in Santa Catarina. For describing the cuticular and medullary pattern of guard hairs, sixty slides were made. Conepatus chinga has a cross-sectional and undulated cuticular pattern and an anisocytic medullary pattern. The description of microstructural patterns of C. chinga makes it easier to conduct studies related to its ecology, increasing the chances to identify hairs found in fecal samples from carnivores in mastofauna studies.

Key words: Roadkill; Skunk; Trichology 


\section{Introduction}

The genus Conepatus consists of four species distributed in American field biomes (WOZENCRAFT, 2005). Out of these, two species occur in the Brazilian territory, Conepatus semistriatus (Boddaert, 1785), observed from the northeastern country to the state of São Paulo, especially in open vegetation of Caatinga, Cerrado, and Pantanal (VIEIRA, 1955; EMMONS; FEER, 1997; EISENBERG; REDFORD, 1999; SILVA et al., 2004; CÁCERES et al., 2008; REIS et al., 2011), and Conepatus chinga, which occurs in field areas and forest edges in the states of Santa Catarina and Rio Grande do Sul and it requires more confirmation for the state of Paraná (REIS et al., 2011).

Conepatus chinga (Molina, 1782) is a small carnivore that has a long, thin, coat, with a general black to dark brown color and two white stripes that may extend from the top of its head down to the sides of the back up to the base of the tail (REIS et al., 2011). These white stripes are highly variable in length and width and they may be even completely absent (TRIGO et al., 2013).

According to Cherem et al. (2007), in the state of Santa Catarina the occurrence of $C$. chinga is restricted to the central portion, and most of the records was due to running over (CHEREM et al., 2004; 2007; CHEREM, 2005). For Paraná, Cáceres (2004) registered C. chinga in the submontane dense ombrophilous forest in the Area of Special Tourist Interest of Marumbi, in Serra do Mar.

The species is regarded as being in decline, due to hunting for fur trade, degradation of fields (EMMONS; HELGEN, 2008), and impact of running over on $C$. chinga populations (ROSA; MAUHS, 2004; CHEREM et al., 2007). Kasper et al. (2009) reported the loss of $40 \%$ of marked animals in a study, mostly due to running over.

Roads are among the environmental changes that caused the most extensive impacts on natural landscapes in the $20^{\text {th }}$ century (BERGALLO; VERA Y CONDE, 2001). Mortality due to running over may be highly damaging to natural populations, especially for species that occur at low densities, such as endangered species and those with a relatively large habitat and low reproductive rates, such as the carnivore species
(SOUSA; MIRANDA, 2010), and sometimes it may be responsible for the record of little-known species.

Identification of the microstructure of hairs has been a widely used tool for identifying mammals, in addition, some studies use it to investigate the occurrence of particular species, in order to know their geographical distribution (ABREU et al., 2011). Some papers use the microstructural patterns of hairs (QUADROS; MONTEIRO-FILHO, 1998a; 1998b; 2006a; 2006b; VASQUEZ et al., 2000) as an auxiliary methodology to mastofauna surveys, but the lack of description of hairs in some Brazilian mammals makes it difficult to use this methodology.

Among the American species of the genus Conepatus, only C. semistriatus had its microstructural pattern described, and its cuticular pattern is pavimentous, undulated, cross-sectional, with continuous scale edges; and the marrow is present, continuous, multiserial, anastomosed, and amorphous (JUÁREZ et al., 2007). For $C$. chinga only the morphological features of the proximal region of hairs were described and the scales have a mosaic-like pattern on the proximal region (VASQUEZ et al., 2000).

Thus, this study aimed to: (1) report 2 new $C$. chinga records for the state of Paraná and 1 for Santa Catarina; (2) introduce a review map of occurrence locations for the states of Paraná and Santa Catarina, southern Brazil; and (3) describe the microstructural patterns of guard hairs in this species.

\section{Material and Methods}

\section{Data collection}

The collection of run-over specimens was performed on the margins of highway BR-280 in the town of Palmas, Paraná, and highway SC-467, in Abelardo Luz, Santa Catarina, in southern Brazil. The region of fields in Palmas is part of Campos Sulinos, which are regarded as part of the Atlantic Forest biome, and this is one of the most threatened Brazilian biomes and has one of the most diverse faunas in the world (MYERS et al., 2000; MIRANDA et al., 2008). Currently the fields in Palmas are characterized by areas altered by grazing, agriculture, and silviculture. 
Highway BR-280 is a cross-country road, which starts in São Francisco do Sul, enters the state of Paraná and ends at the border between the states of Santa Catarina and Paraná, in the town of Dionísio Cerqueira, Santa Catarina, which borders Argentina. This highway is an important corridor for the flow of northern plateau production in the state of Paraná to the Port of São Francisco do Sul.

\section{Occurrence of Conepatus chinga}

To check locations with occurrence of $C$. chinga, a literature review of articles and books was carried out to obtain the species records for the states of Santa Catarina and Paraná, in southern Brazil.

\section{Microstructural pattern of guard hair}

We collected manually, for analyzing the microstructural pattern of hairs, small tufts of guard hairs from the back at the intersection region between the median line and the scapular line, from the 3 run-over individuals found. The hairs were pulled away so that the bulb and apex were not damaged. By means of them, 60 slides of the cuticular and medullary pattern were made, using 20 guard hairs of each specimen, according to the identification techniques described by Quadros and Monteiro-Filho (2006a; 2006b). The preparation of slides was performed in the Laboratory of Zoology of the Paraná State University (UNESPAR), in the campus União da Vitória.

\section{Results}

\section{New records and distribution of Conepatus chinga}

The two first run-over specimens were found on highway BR-280, in the state of Paraná, and the third on highway SC-467, in Santa Catarina, southern Brazil. The first specimen (Figure 1A) was found on February 20, 2011 (2634'59'S; 51 $\left.{ }^{\circ} 52^{\prime} 33^{\prime \prime} \mathrm{W}\right)$ and the second (Figure 1B) on November 28, 2011 (26³4'24,23”S; 514'31,52”W), both in Palmas, Paraná. The third specimen (Figure 1C) was found near the crossroads to arrive at the town of Abelardo Luz, Santa Catarina, on February 13, 2014 (26²7’26,88’'S; 52¹5,5’34”W).

FIGURE 1: Conepatus chinga (Molina, 1782) run-over specimens found between 2011 and 2014. a) and b) on highway BR-280, in the town of Palmas, Paraná. c) highway SC-467, in the town of Abelardo Luz, Santa Catarina.

a)

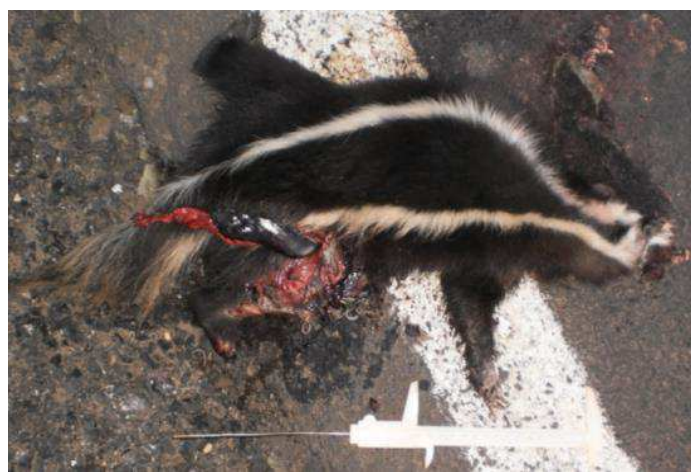

b)

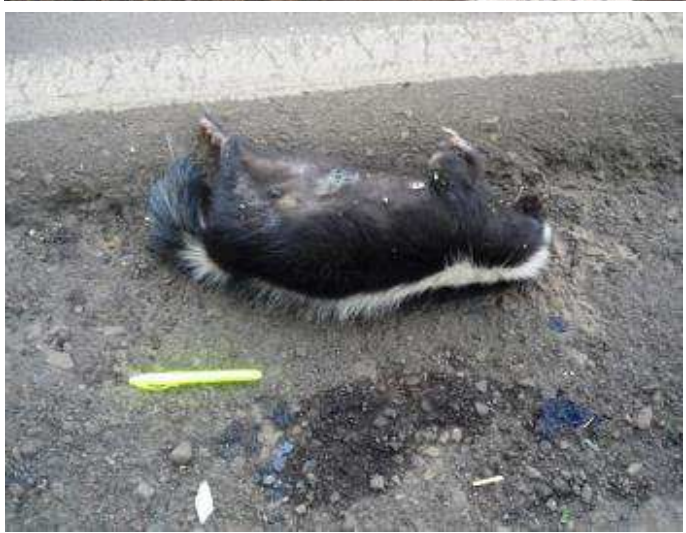

c)

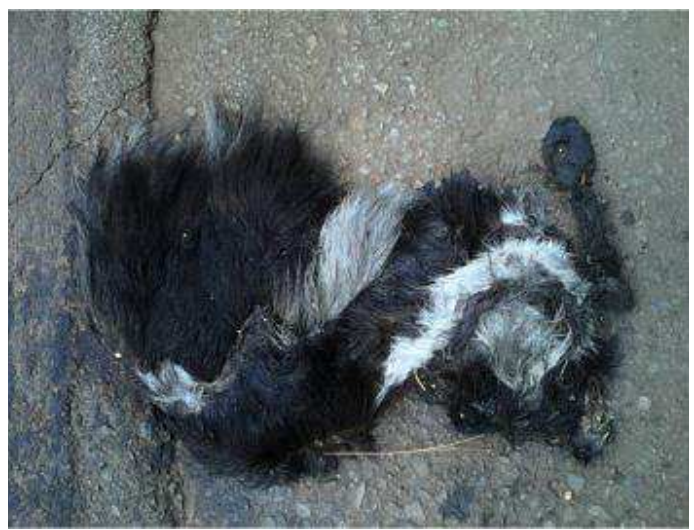

Bibliographical data register the species for 17 towns in the state of Santa Catarina (Table 1) and there is only 1 record for the state of Paraná, in the region of Serra do Mar (Figure 2). 
TABLE 1: Documented distribution and new records of Conepatus chinga for the states of Paraná and Santa Catarina, southern Brazil.

\begin{tabular}{ll}
\hline \multicolumn{1}{c}{ Source } & \multicolumn{1}{c}{ Municipalities in Santa Catarina } \\
\hline Cherem et al. (2007) & Água Doce, Erval Velho, Bom Retiro, Curitibanos, São Cristóvão do Sul, Ponte Alta, Correia \\
& Pinto, Lages, Bocaina do Sul, Painel, São Joaquim \\
Kasper et al. (2012) & Campo Belo do Sul \\
Cherem et al. (2004) & Bom Jesus da Serra, Bom Retiro, São Joaquim \\
Cherem (2005) & Celso Ramos, Campos Novos \\
Cimardi (1996) & Blumenau, Bom Retiro, Lages, Pouso Redondo \\
This study & Abelardo Luz \\
\hline & Municipalities in Paraná \\
\hline Cáceres (2004) & Morretes - Serra do Mar in the state of Paraná \\
This study & Palmas \\
\hline
\end{tabular}

FIGURE 2: Records of Conepatus chinga for the states of Paraná and Santa Catarina, southern Brazil.

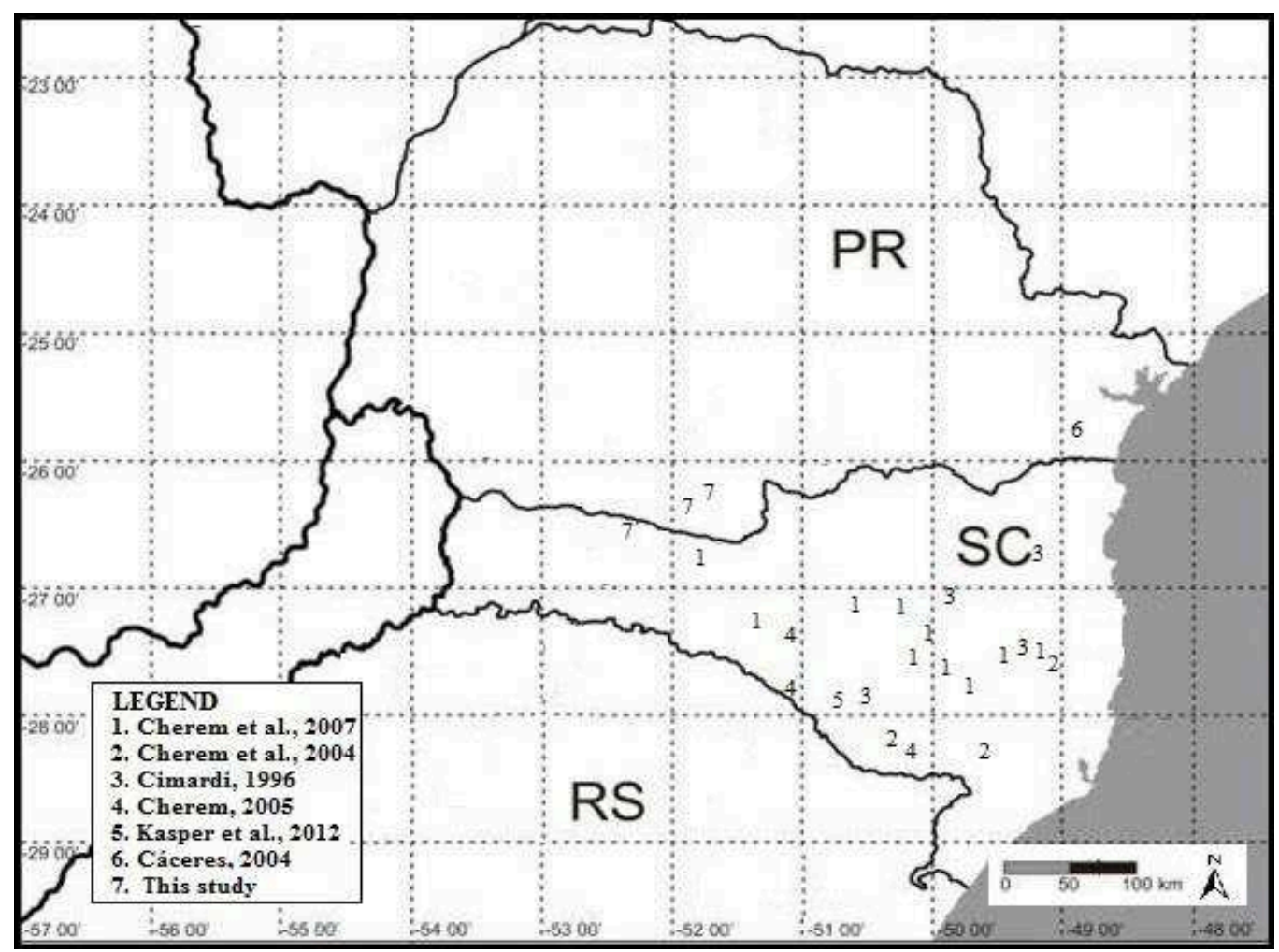

\section{Microstructural pattern of guard hair}

Guard hair in $C$. chinga have a cross-sectional and undulated cuticular pattern, where scales do not have defined corners, their contour is undulated and it constitutes a set of smooth transitions between protrusions and recesses of varying depth (Figure 3A).
Medulla is present and continuous over the whole length of the guard hair, it is possible to discern medullary cells containing air and pigments, embedded in the center of cortical matrix (Figure 3B). The medullary pattern found is anisocytic, where cells have a similar shape, but different sizes that may reach the diameter of medulla.

No differences were found between the cuticular and medullary patterns of the $60 C$. chinga guard hairs. 
FIGURE 3: Microstructural pattern of Conepatus chinga. a) Cuticular pattern and b) Medullary pattern.

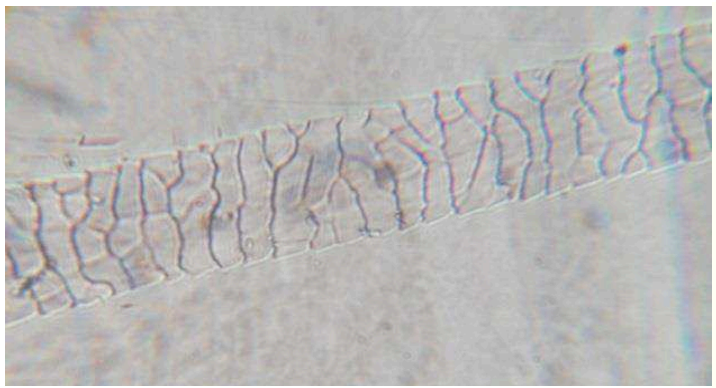

a)

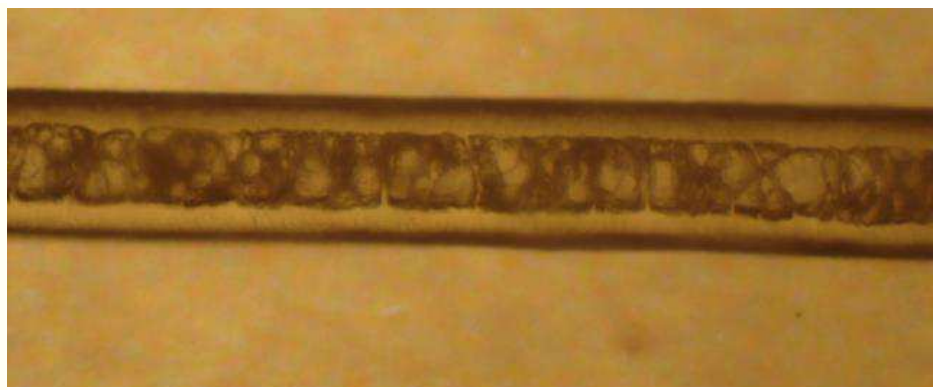

b)

\section{Discussion}

Conepatus chinga has nocturnal/crepuscular terrestrial habits (CHEIDA et al., 2006), inhabiting open areas, from the Paraguayan Chaco to the steppes in Cordillera foothills (REDFORD; EISENBERG, 1992) and, above all, the grasslands in Pampa (KASPER et al., 2009). There are records of the species using forest environments in Serra do Mar in the state of Paraná (CÁCERES, 2004). Nevertheless, this record may be associated with proximity to open areas, since vegetation in the area is influenced by the mixed ombrophilous forest.

Skunks, in general, and Conepatus, in particular, are associated with open environments; $C$. humboldtii occurs in association with desert environments; $C$. semistriatus has its distribution associated with Caatinga and Cerrado, with only occasional records in areas of the Atlantic Forest; and C. chinga has most of its distribution associated with Pampa and Andean steppes. Thus, it is possible that forest areas such as the Atlantic Forest represent barriers to species dispersal. Records such as those made by Cáceres (2004) may also represent an occasional occurrence or an expanded occurrence area due to fragmentation. Expanded species' occurrence areas have been observed in fragmented forest areas in Rio Grande do Sul, in which the species started being registered where it was not known by the population (Carlos Benhur Kasper, personal observation).

Kasper et al. (2009) regard as controversial the use of forest areas by C. chinga, as reported by Cáceres (2004). Studies conducted by Kasper et al. (2009), in Rio Grande do Sul, suggest the species is restricted to open vegetation areas.
So far, taking this paper into account, there are 3 records of $C$. chinga for the state of Paraná. In the state of Santa Catarina, records are distributed into 17 municipalities, most of them occurred by means of run-over specimens associated with open areas in the central portion of the state (CHEREM et al., 2004; 2007; CHEREM, 2005; KASPER et al., 2012), showing the huge impact of roads on wildlife.

Conepatus chinga had a cross-sectional and undulated cuticular pattern and an anisocytic medullary pattern, described for some carnivores by Quadros and Monteiro-Filho (2006a; 2006b) and typical of some Neotropical mammal species (QUADROS; MONTEIROFILHO, 2006b). Vasquez et al. (2000) described the morphological features of the proximal region in $C$. chinga, where scales have a mosaic-like pattern in the proximal region, differing from that obtained in this study, in which the shield region was described according to the methods adopted by Quadros and Monteiro-Filho (2006a). The characteristics of the patterns described for C. semistriatus by Juárez et al. (2007), are similar to those of C. chinga, differing only in a few features in the arrangement of cells in the medulla, something which may be used to distinguish the two species. The description of microstructural patterns of $C$. chinga makes it easier to conduct studies related to its ecology, increasing the chances to identify hairs found in fecal samples from carnivores in mastofauna studies.

With these new records, the occurrence of $C$. chinga becomes confirmed for the natural field areas in the town of Palmas, Paraná, and Abelardo Luz, Santa Catarina, however, there is a for need further studies, to confirm the species in submontane dense ombrophilous forest and 
in deforested areas of this plant formation, and actions aimed at the conservation of this carnivore species.

\section{References}

ABREU, M. S. L.; CHRISTOFF, A. U.; VIEIRA, E. M. Identificação de marsupiais do Rio Grande do Sul através da microestrutura dos pelos-guarda. Biota Neotropica, Campinas, v. 11, n. 3, p. 391-400, 2011.

BERGALlO, H. G.; VERA Y CONDE, C. F. O. Parque Nacional do Iguaçu e a estrada do Colono. Ciência Hoje, Rio de Janeiro, v. 29, n. 174, p. 37-39, 2001.

CÁCERES, N. C. Occurrence of Conepatus chinga (Molina) (Mammalia, Carnivora, Mustelidae) and other terrestrial mammals in the Serra do Mar, Paraná, Brazil. Revista Brasileira de Zoologia, Curitiba, v. 21, n. 3, p. 577-579, 2004.

CÁCERES, N. C.; CARMIGNOTTO, A. P; FISCHER, E.; SANTOS, C. F. Mammals from Mato Grosso do Sul, Brazil. Check List, Rio Claro, v. 4, n. 3, p. 321-335, 2008.

CHEIDA, C. C.; NAKANO-OLIVEIRA, E.; FUSCO-COSTA, R.; ROCHA-MENDES, F.; QUADROS, J. Ordem Carnivora. In: REIS, N. R.; PERACCHI, A. L.; PEDRO, W. A.; LIMA, I. P. (Ed.). Mamíferos do Brasil. Londrina: Imprensa da UEL, 2006. p. 231-276.

CHEREM, J. J. Registros de mamíferos não voadores em estudos de avaliação ambiental no sul do Brasil. Biotemas, Florianópolis, v. 18, n. 2, p. 169-202, 2005.

CHEREM, J. J.; KAMMERS, M.; GHIZONI-JR, I. R.; MARTINS, A. Mamíferos de médio e grande porte atropelados em rodovias do estado de Santa Catarina, sul do Brasil. Biotemas, Florianópolis v. 20, n. 3, p. 81-96, 2007.

CHEREM, J. J.; SIMÕES-LOPES, P. C.; ALTHOFF, S.; GRAIPEL, M. E. Lista do Mamíferos do estado de Santa Catarina, Sul do Brasil. Mastozoología Neotropical, San Miguel de Tucumán, v. 12, n. 2, p. 151-184, 2004.

CIMARDI, A. V. Mamíferos de Santa Catarina. Florianópolis: FATMA, 1996. 302 p.

EISENBERG, J. F.; REDFORD, K. H. Mammals of the neotropics: the central neotropics. Ecuador, Peru, Bolivia, Brazil. Chicago: University of Chicago Press, 1999. 609 p.

EMMONS, L. H.; FEER, F. Neotropical rainforest mammals: a field guide. Chicago: University of Chicago Press, 1997. 307 p.

EMMONS, L.; HELGEN, K. Conepatus chinga. In: IUCN (Ed.). IUCN Red list of threatened species. Version 2008. Disponível em: <http:www.iucnredlist.org>. Acesso em: 12 fev. 2014.

JUÁREZ, D.; ESTRADA C.; BUSTAMANTE M.; QUINTANA Y.; MOREIRA J.; LÓPEZ J. E. Guía ilustrada de pelos para la identificación de mamíferos medianos y mayores de Guatemala. Guatemala: Universidad de San Carlos de Guatemala, 2007. 107 p. KASPER, C. B.; BASTAZINI, V. A. G.; SOARES, J. B. G.; FREITAS, T. R. O. Abundance of Conepatus chinga (Carnivora, Mephitidae) and other medium-sized mammals in grasslands of southern Brazil. Iheringia Série Zoologia, Porto Alegre, v. 102, p. 303-310, 2012.

KASPER, C. B.; RODRIGUES, M. L. F.; CAVALCANTI, G. N.; FREITAS, T. R. O.; RODRIGUES, F. H. G.; OLIVEIRA, T. G.;
EIZIRIK, E. Recent advances in the knowledge of Molina's Hognosed Skunk Conepatus chinga and Striped Hog-nosed Skunk $C$. semistriatus in South America. Small Carnivore Conservation, Starkville, v. 41, p. 25-28, 2009.

MIRANDA, J. M. D.; MORO RIOS, R. F.; PASSOS, F. C.; Contribuição ao conhecimento dos mamíferos dos Campos de Palmas, Paraná, Brasil. Biotemas, Florianópolis, v. 21, n. 2, p. $97-$ 103,2008

MYERS, N.; MITTERMEIER, R. A.; MITTERMEIER, C. G.; FONSECA, G. A. B.; KENT, J. Bidiversity hotspots for conservation priorities. Nature, London, v. 403, p. 853-858, 2000.

QUADROS, J.; MONTEIRO-FILHO, E. L. A. Effects of digestion, putrefaction, and taxidermy process on Didelphis albiventris hair morphology. Journal of Zoology, London, v. 244, n. 3, p. 331-334, 1998a.

QUADROS, J.; MONTEIRO-FILHO, E. L. A. Morphology of different hair types of Didelphis albiventris and its usage in hair identification. Journal of the Brazilian Association for the Advancement of Science, Campinas, v. 50, n. 5, p. 382-385, 1998 b.

QUADROS, J.; MONTEIRO-FILHO, E. L. A. Coleta e preparação de pêlos de mamíferos para identificação em microscopia óptica. Revista Brasileira de Zoologia, Curitiba, v. 23, n. 1, p. 274-278, 2006a.

QUADROS, J.; MONTEIRO-FILHO, E. L. A. Revisão conceitual, padrões microestruturais e proposta nomenclatória para os pêlosguarda de mamíferos brasileiros. Revista Brasileira de Zoologia, Curitiba, v. 23, n. 1, p. 279-296, 2006b.

REDFORD, K. H.; EISENBERG, J. F. Mammals of the Neotropics: the southern cone Chile, Argentina, Uruguay, Paraguay. Vol. 2. Chicago: University of Chicago Press, 1992. 460 p.

REIS, N. R.; PERACCHI, A. L.; PEDRO, W. A.; LIMA, I. P. Mamíferos do Brasil. Londrina: Universidade Estadual de Londrina, 2011. 441 p.

ROSA, A. O.; MAUHS, J. Atropelamento de animais na rodovia RS-40. Caderno de Pesquisa, Série Biologia, Santa Cruz do Sul, v. 16, n. 1, p. $35-42,2004$.

SILVA, J. M. C.; TABARELLI, M.; FONSECA, M. T.; LINS, L. V. Biodiversidade da caatinga: áreas e ações prioritárias para a conservação. Brasília: Ministério do Meio Ambiente, UFPE, 2004. $382 \mathrm{p}$.

SOUSA, M. A. N.; MIRANDA, P. C. Mamíferos terrestres encontrados atropelados na rodovia BR-230/PB entre Campina Grande e João Pessoa. Biofar: Revista de Biologia e Farmácia, João Pessoa, v. 4, n. 2, p. 72-82, 2010.

TRIGO, T. C.; FONTOURA-RODRIGUES, M. L.; KASPER, C. B. Carnívoros Continentais. In: WEBER, M. M.; ROMAN, C.; CÁCERES, N. C. (Ed.). Mamíferos do Rio Grande do Sul. Santa Maria: Editora UFSM, 2013. p. 343-404.

VASQUEZ, D. E.; PEROVIC, P. G.; OLSEN, A. A. Patrones cuticulares y medulares de pelos de mamíferos del Noroeste Argentino (Carnivora Y Artiodactyla). Mastozoologia Neotropical, Argentina, v. 7, n. 2, p. 131-147, 2000.

VIEIRA, C. C. Lista remissiva dos mamíferos do Brasil. São Paulo: Arquivos de Zoologia, 1955. 474 p.

WOZENCRAFT, W. C. Order Carnivora. In: WILSON, D. E.; REEDER, D. M. (Ed.). Mammal species of the World. Baltimore: The Johns Hopkins University Press, 2005. p. 532-628. 